\title{
TYPOVÉ ZAŘAZENÍ HRADU SKÁLA U PŘEŠTIC
}

\author{
FRANTIŠEK GABRIEL - LUCIE KURSOVÁ
}

Abstrakt: Označeni ganerbenburg považuji někteři autoři za dispozični typ hradů. Článek upozorňuje na chybnost tohoto př́stupu a doporučuje uživání jiného druhového jména a jeho definici.

Klíčová slova: ganerbenburg - hrad-středověk-hradni jádro.

\section{Typological classification of the Skála castle, near Přšstice}

Abstract: Some historians believe that the term ganerbenburg denotes a layout type of castles. This article points out the incorrectness of this approach, proposing the use of a different term and its definition.

Key words: ganerbenburg - castle - Middle Ages - castle core.

Hrad Skálu (k. ú. Zálesí u Příchovic, okr. Plzeň-jih) řadí T. Durdík $(1999,500)$ „(..) do u nás vzácné kategorie v Německu označované jako Ganerbenburg“. Termín ganerbenburg se objevuje $\mathrm{v}$ dobových pramenech středověkého německého prostředí a $\mathrm{z}$ něho také byla dovozena jeho definice (např. Piper 1912, 571-580). Vychází ze záznamů řady lokalit, ve kterých písemné prameny uvádějí na jednom hradě více majitelů v různých vzájemných vazbách. Za další typickou vlastnost sídel autor považuje dvě a více hradních jader, která shledával na řadě lokalit řazených k tomuto typu (např. Salzburg, Bavorsko; Eltz, Porýní-Falc; Schwarzburg, Durynsko; Hatzfelden, Hesensko; a další, jak je uvádí např. Alsdorf 1980).

V Čechách termín ganerbenburg do literatury zavedla a definici naznačila D. Menclová $(1972,167,169)$. Shodně $\mathrm{s} D$. Menclovou podal dnes u nás obecně přijímanou definici tohoto typu hradu T. Durdík $(1999,142) .{ }^{1}$ Autor předpokládá, že mezi takto řazená sídla náleží „,(..) hrad obsahujicí více jader, která byla sídly více samostatných majitelủ. Ti měli většinou vnější opevnění eventuálně hospodářské a provozní části hradu ve společném vlastnictví. V Německu (...) mohl obsahovat až 10 jader, každé s palácem a věží. (...) Hrady stavěné od počátku jako Ganerbenburg jsou v Čechách velmi vzácné a v obou známých připadech (Choustník a Skála u Přětic) obsahuji pouze dvě jádra" (Durdík 1999, 142).

V roce 1988 rozšíríili typ ganerbenburgu na území naší republiky Z. Měřínský-M. Plaček $(1988,240)$ o moravský hrad Rokštejn a následně spojili s takto chápaným dispozičním typem několik hradů i další autoři. Otázku definice znovu otevřel v roce 2003 na Mezinárodní konferenci archeologie středověku M. B. Soukup v referátu „K otázce rozdělených hradů“, jehož přepracovanou verzi publikoval o dva roky později (Soukup 2005). Odvolává se na právní rozbor termínu a jeho forem v odborné literatuře a srovnává jej s českými právními pojmy nedíl a spolek. V závěru autor upozorňuje, že pojem ,....) ganerbenburg je právní termín, který náleži do oblasti německého středovékého práva a nepatři do české terminologie, kde je třeba uživat pojmy, hrad v nedilu' nebo ,hrad ve spolku“" “2 V žádném případě jej nelze považovat za termín dispozičního typu hradů a definovat jej více jádry. Takový hrad doporučuje „,...) pouze popisně označit jako hrads, vícedilnou dispozici “ nebo ,hrad rozdělený na více částí ““.

Je tedy zřejmé, že termín ganerbenburg náleží do historicko-právní roviny. Názor přijal i T. Durdík $(2008,28)$, upozornil však na skutečnost, že ,(...) jde o zaběhnutý a běžně uživaný termín evropské, minimálně německy mluvici kastelologie pro určité rešení podoby hradního jádra“ a M. B. Soukupem navrhované označení, užívané pro něco zcela odlišného, za nepřijatelné. Problém však není v pouhém názvu hradního typu, ale v definici, která se pokouší propojit

1 Prvně, a to shodně s O. Piperem i D. Menclovou, hrad typu ganerbenburg T. Durdík definoval v roce 1984 (Durdík 1984, 96, 137), naposledy se pak autor tématu dotkl v roce 1999 (Durdík 1999, 142).

2 Hranice mezi vlastnictvím jedince a „nedílem“, tedy neděleným majetkem více vlastníků není zcela jasná. Ideální stav předpokládá stejný podíl majitelů bez rozdělení čehokoliv. Tomu ovšem ganerbenburg neodpovídá, nebot' majitelé drži svá hradní jádra. I v případě držby v nedílu (častá situace, kdy otec rozdělil majetek mezi starší syny a sám si s mladšími syny zanechal část, kterou s nimi držel v nedílu) nepochybně vzniklo vydělení např. místností (pokoje otce, pokoj syna A a pokoj syna B), pater, jednotlivých staveb hradu a podobně. Zdá se, že důležitým prvkem nedílu bylo společné vlastnictví po stránce finanční, kdy při prodeji by všichni vlastníci v nedílu dostali stejnou část úhrady za sídlo. 
oba druhy historických pramenů. Ty však, jak ostatně upozornil již M. B. Soukup $(2005,584)$, vzájemně nekorelují, mohou však, ale také nemusí, mít vztah kauzální. Z tohoto důvodu považujeme výše uvedenou definici za metodicky chybnou. Jedná se o dvě na sobě nezávislé vlastnosti: na jedné straně o majetkové poměry, získávané z dobových záznamů o dynamickém systému, a na straně druhé o modely struktury sídel, interpretované z reliktů a stop složených artefaktů (hradů). Vztah mezi majetkovými poměry s řadou variant a modely struktury hradů tak stojí ve třech různých vztazích:

1) Hrad má dva nebo více majitelů, ale pouze jedno jádro.

2) Hrad má dva nebo více majitelů a dvě nebo více jader.

3) Hrad má jednoho majitele, ale dvě nebo více jader.

Z historicko-právního hlediska stojí vedle hradu (míněno je ovšem spíše hradní zboží) s jedním majitelem i hrady s více majiteli, a to bud' v nedílu, nebo ve spolku. Z hlediska kastelologického pak vedle hradů s jedním hradním jádrem stojí i hrady se dvěma či více jádry.

Pokusíme-li se nyní rozhodnout, zda hrad Skála náleží mezi hrady s více majiteli, obrátíme se k dosud nepřekonanému A. Sedláčkovi (1996, 173), který provedl středověké a raně novověké zápisy o jeho majetkových poměrech podrobně. Jako první zmínku autor uvádí predikát Viléma (Wilhelmus de Scala), zapsaný roku 1318 (RBM III, 182 č. 445). Založení hradu přisuzuje rozdělení rýzmberského zboží (Sedláček hrad jmenuje Rýžemberk), po kterém se Vilém se svými bratry před rokem 1318 psal. Rozdělení rýzmberského zboží vyvolalo potřebu vybudovat nové sídlo pro část získanou Vilémem. Tento Sedláčkův model převzala D. Menclová (1972a, 99), která rozdělení rýzmberského zboží klade, bohužel bez uvedení pramene, k roku 1310. T. Durdík $(1999,499)$ sice první zmínku o hradě označuje za pouhý doklad jeho držení Vilémem, avšak, jak vyplývá z následujícího textu, Sedláčkův model založení sídla rovněž přijímá.

Zdá se tedy, že za zakladatele hradu považuje odborná literatura pouze jediného stavebníka, čímž je ovšem držba hradu dvěma majiteli při založení sídla popřena. Když však rozšiříme okruh hledání více současných majitelů o pozdější období majetkových poměrů hradu Skála, držbu hradu dvěma samostatnými majiteli v dobových pramenech nalezneme. Je jím krátké období v závěru 14. století. Tehdy totiž, někdy mezi rokem 1379, kdy je naposledy jmenován majitel hradu Vilém ze Skály (Sedláčka 1996, 173), a rokem 1385, ve kterém dosazují plebána na hradním zboží „(...) Hinconis [správně Břeněk; Sedláček 1996, 174] et Puthonis fratrum de Skala (...)“ (LC III-IV, 171), získali, nejspíše jako dědictví, skalské dominium oba bratři. Spolu jej ovšem drželi pouze krátce, nebot' již roku 1386 dosazoval plebána tamtéž pouze jeden z nich - „(...) Pothonis de Skala“ (LC III-IV, 175). Teprve později, asi po smrti Půty, se dostal hrad Skála do držení Břeňka (Sedláček 1996, 174).

Z historicko-právního hlediska se pravděpodobně mohlo na krátkou dobu stát zboží hradu Skála majetkem dvou samostatných vlastníků. Pochybnosti vyjádřené v předchozí větě plynou z nedostatku dobových záznamů o majetkových poměrech, jak je ostatně v psaných pramenech středověku a raného novověku u nás běžné, a nedovolují tak jednoznačné určení majetkových vztahů. Záznamů, často i s uvedením držby v nedílu, nebo alespoň jejich náznaků, uvádí odborná literatura značné množství (některé viz Soukup 2005, 583). Zdá se tedy, že se ve středověku a raném novověku jednalo o časté uplatnění této právní formy vlastnického práva, jak také naznačuje jeho široké rozvedení v odborné literatuře (Vaněček 1976, 102-106, 508-518). Otázkou ovšem zůstává, do jaké míry společné vlastnictví ovlivnilo stavbu či přestavbu sídel.

Odpověd' na položenou otázku hledáme ve formální struktuře. Ta by se podle modelu T. Durdíka $(1999,142)$ měla v dispozičním typu autorova hradu ganerbenburg, tedy hradu se dvěma či více jádry, projevit oddělením jednotlivých hradních jader, jejich vybavením věží a palácem, společným hospodářským a provozním dílem a uzavřením sídla společným vnějším opevněním. Rozklad prvků hradu však přináší řadu nedořešených problémů. Pomineme-li 
otázku definice kategorie hrad (Gabriel 2002), pak stojíme před otázkami pojmů jednotlivých hradních dílů, jejich zástavby a opevnění.

Za prvořadý úkol určení hradu se dvěma či více jádry považujeme vymezení jednotlivých hradních dílů z celkové plochy staveniště hradu. Nejedná se však pouze o hradní jádro, ale o všechny díly, jejichž rozdílnost je důvodem k odmítnutí M. B. Soukupem $(2005,584)$ doporučeného popisného označení sídel se dvěma či více jádry „hrad s vícedílnou dispozici““ nebo „hrad rozdělený na vice části“. Takových hradů je totiž podle již zavedené kastelologické terminologii převážná většina, a musíme proto předložený návrh shodně s T. Durdíkem (2008, 28) odmítnout.

Zdánlivě jednoduchý úkol však naráží, jako ostatně většina úkolů dalších, na míru archeologizace. Ta může být příčinou nepřítomnosti zdí vymezujících jednotlivé díly hradu. V některých případech může tuto „chybu“ odstranit archeologický výzkum, ovšem jeho výsledky rovněž limituje archeologizace, nemluvě o možnosti ,ideového dělení hradu“. S tím musíme počítat v př́ípadě hradního rozdělení mezi několik majitelů, většinou v př́ibuzenských vztazích, kteří sídlo užívali společně, nikoli však v nedílu, ale často podle závěti, jak tomu bylo např́íklad u hradu Lipý (k. ú. Česká Lípa, okr. Česká Lípa; Panáček 2004).

Ještě méně jistoty často nabízí určení funkce jednotlivých dílů. Jako možnost se nabízí hradní jádro, předhradí a přihrádek, případně, a to především od goticko-renesančního období, různé formy vydělených opevnění. Základním kritériem pro jejich určení je vedle dělicího zdiva komunikační schéma (Gabriel-Kursová 2017, 32) a jejich stavební vybavení. Z textu T. Durdíka $(1999,142)$ lze dovodit, že hradní jádra mají u hradů se dvěma či více jádry obsahovat palác a věž. Autor ovšem neuvádí, o jakou věž se má jednat, zda o věž obytnou (donjon) či o věž obrannou (bergfrit), nebo je-li její specifikace irelevantní, jak se zdá na modelu hradu Salzburg (Bad Neustadt, Bavorsko, SRN, obr. 1). ${ }^{3}$

Ovšem ani definice věže, donjonu a bergfritu nejsou jednoznačné a váže se k nim řada otázek (např. Durdík 1977; 1999, 590, 56-57, 117-118; Durdík-Bolina 2001, 30-42; Gabriel 2008, 33-37). ${ }^{4}$ Důvodem je zřejmě obtížné určení funkce, kterou sice naznačuje řada znaků, ale ty jsou patrné pouze na dochovaných stavbách, a nikoli vždy, takže jejich zařazení často není jednoznačné. Navíc vedle tradičních deskriptorů (Gabriel 2008, 39-41) je nezbytné zohlednit i jejich situování v terénu. Typickou ukázkou je hrad Trosky (k. ú. Troskovice, okr. Semily). Stavby založené na sopouších vyplněných olivinickým nefelinitem a vypreparovaných přírodou (Kukal a kol. 2010, 29-30) náleží svojí dispozicí samy o sobě k palácům. Ve spojení se svým podložím je však musíme zařadit mezi věže a podle přístupu vysoko nad jejich patou jako věže obranné. Podobně se chovají i domnělá jádra skalních hradů (Gabriel-Smetana 1981, 39-40), která, jak se ukazuje, sloužila nejspíše rovněž jako obranné věže (Gabriel 2008, 49).

S ohledem na požadavek vybavení ganerbenburgů (hradních jader) vedle věže i palácem se zdá, že T. Durdík $(1999,142)$ mínil ve své definici věž obrannou (bergfrit). Přijmeme-li chápání věže jako stavby obranné, pak druhá stavba musela sloužit trvalému bydlení. I zde však stojíme před otázkou, zda stavbou pro trvalé bydlení mohl být výhradně palác, nebo i donjon, prŕípadně věžový palác či jiná forma obydlí. ${ }^{5}$ I přes ty to nedostatky přijímáme definici jádra jako dílu hradu vybaveného dvojicí staveb - věží a palácem - blíže nespecifikovaných.

Pokusíme-li se vyhledat předložené znaky hradních jader na hradě Skála, narazíme především na problém archeologizace sídla. Ze základních znaků odlišujících věž od paláce (Gabriel 2008) nám chybí u všech staveb výškové rozměry, takže o jejich zařazení rozhodujeme pouze na základě dispozice. Platnost již značně obecného určení definičních znaků tak ještě více

3 Funkce jednotlivých věží je převzata od O. Pipera (1912, 573).

4 V sousedním Německu se v minulosti charakteristice a různým formám donjonů a bergfritů podrobně věnoval např. O. Piper (1912, 173247). V poslední době např. celý soubor prací publikovaných ve sborníku Wohntürme (2002).

5 Obecně uživané termíny obytná věž nebo donjon jsou jasně odlišitelné od termínu palác rozdílným poměrem mezi dispozičním a výškovým rozměrem věže (např. Durdík 1999, 590). Poněkud nejasný je pojem věžový palác. Spojení s pojmem obytná věž (donjon), jak jej chápe např. D. Menclová $(1972,201)$ nebo J. Pachner $(2012,258)$, je pouhým zmnožením užívaných termínů, jindy však, např. v práci I. Lehkého (2012, $176,186)$, vyvolává dojem použití pojmu věžový palác pro dalši typ stavby, který autor řadí do typu věže, avšak nedefinuje jeho odlišnost od typu obytná věž a od typu palác. Nejasné jsou i jiné formy, které uživá německá odborná literatura jako např. Steinhaus, Kemenate a další. 


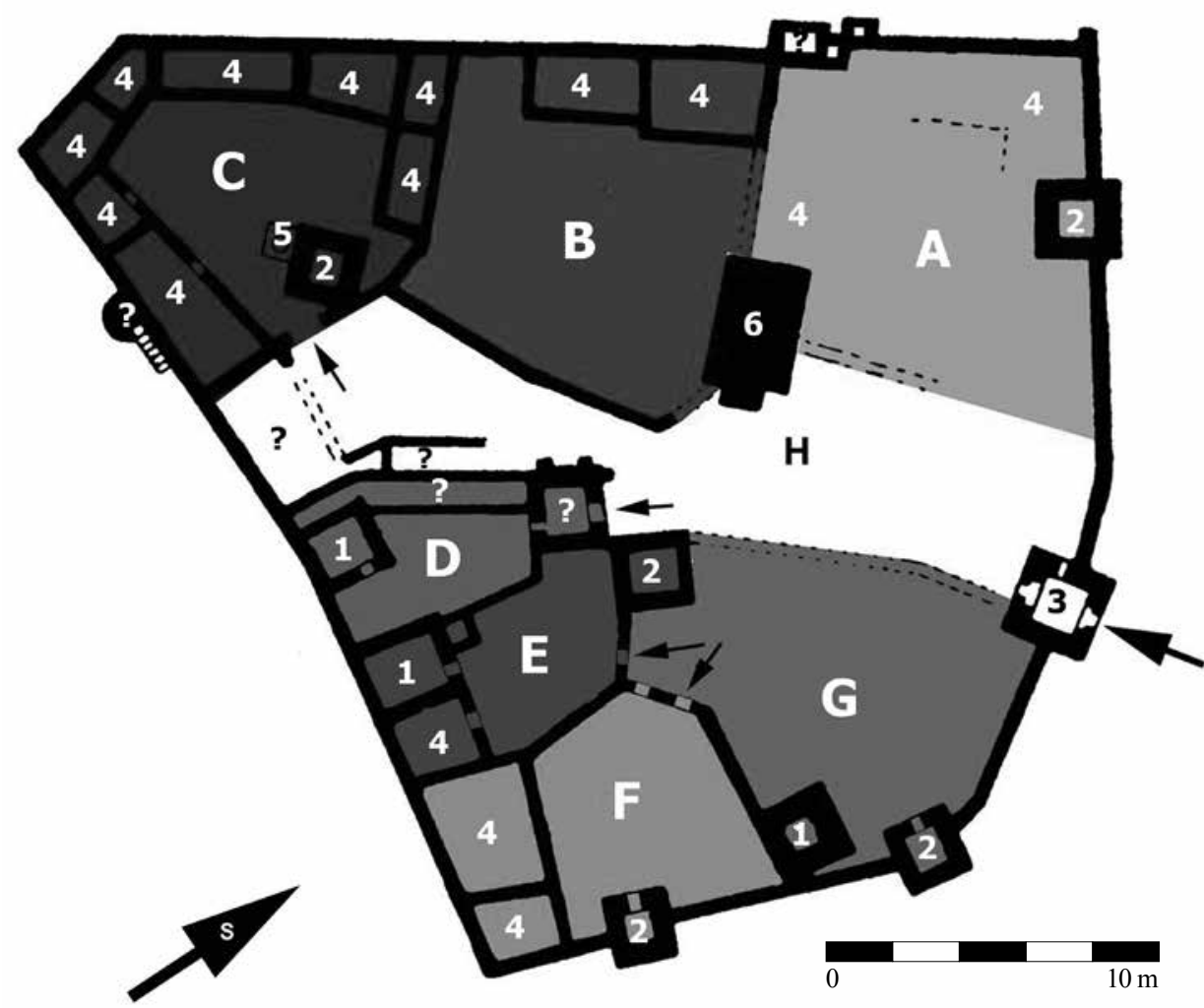

Obr. 1. Schematický plán hradu Salzburg. A - hradní jádro rodu von Schneberg; B - hradní jádro Voit von Salzburg; C - hradní jádro Voit von Salzburg; D - hradní jádro bez uvedeného majitele; E - hradní jádro rodu von Brende; F - hradní jádro bez uvedeného majitele; $\mathbf{G}$ - hradní jádro rodu von Boria; $\mathbf{H}$ - společný majetek vlastníkủ jader; 1 - donjon; 2 - bergfrit; 3 - věžová brána; 4 - palác; 5 - studna; 6 - kaple sv. Bonifáce; ? - stavby bez uvedené funkce. Podle Piper 1912, 572, obr. 582.

Abb. 1. Schematischer Plan von Burg Salzburg. A - Burgkern der Familie von Schneberg; B - Burgkern Voit von Salzburg; C - Burgkern Voit von Salzburg; D - Burgkern ohne Angabe des Besitzers; E - Burgkern der Familie von Brende; F - Burgkern ohne Angabe des Besitzers; G - Burgkern der Familie von Boria; H - gemeinsames Eigentum der Kernbesitzer; 1 - Donjon; 2 - Bergfried; 3 - Turmtor; 4 - Palas; 5 - Brunnen; 6 - St. Bonifatiuskapelle; ? - Gebäude ohne Angabe der Funktion. Nach Piper 1912, 572, Abb. 582.

znehodnocujeme, nebot' korelace mezi rozměry dispozice a výškovými rozměry nemusí nutně odpovídat našim představám. Avšak i při přijetí shodného modelu D. Menclové (1972a, 98-99) i T. Durdíka (1984, 137, 139; 1999, 500) není dispozice hradu jednoznačná (obr. 2).

Nejasná zůstává již otázka předhradí. Oba autoři jej spojují s př́íkopy a valy přisedajícími od severozápadní strany k několikrát přerušenému skalnímu hřebeni proterozoického buližníku (Kukal 2010, 19), který vystupuje nad severovýchodně ukloněný svah kupy Černý les. Podle T. Durdíka $(1999,500)$ nelze vyloučit jejich starší původ a přesnější datace nás tak staví před otázku jejich vazby ke středověkému sídlu na skalním hřebeni. Již sama forma valového opevnění, pokud ovšem valy nevznikly rozvalením obvodových zdí, je pro 14. století značně netypická. Avšak i z prŕípadné datace valového opevnění do 14. století mohou vyplynout otázky další. Vymezovalo opevnění skutečně předhradí, a pokud ano, sloužilo oběma hradním jádrům nebo mělo každé své vlastní předhradí, jak naznačuje plán T. Durdíka (2008a, 133)? Jsou to otázky velmi důležité, nebot' vztah plochy vymezené valovým opevněním ke středověké zástavbě je jediným spojovacím prvkem obou hradních jader. Jejich pozitivní interakci však bez archeologického výzkumu opevnění a plochy nemůžeme jednoznačně prokázat. 


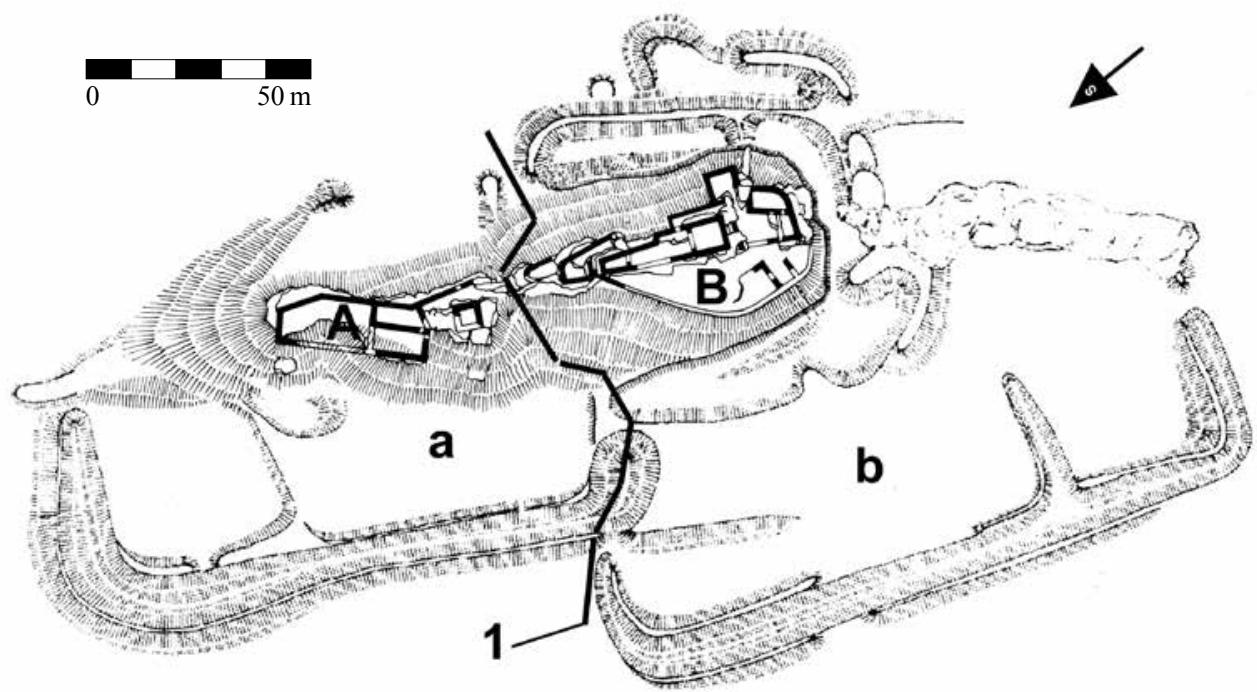

Obr. 2. Upravený plán hradu Skála podle T. Durdíka. A - severní jádro; a - severní předhradí; B - jižní jádro; b - jižní předhradí; 1 - hranice částí hradu. Podle Durdík 1984, 138; 2008a, 133.

Abb. 2. Bearbeiteter Plan von Burg Skála. A - nördlicher Burgkern; a - nördliche Vorburg; B - südlicher Burgkern; b - südliche Vorburg; 1 - Grenze der Burgteile. Nach Durdík 1984, 138; 2008a, 133.

Jednoznačné není ani hodnocení rozlohy a funkce staveb hradních jader. Míra archeologizace, tj. přibližně $50 \%$ zdí degradovaných na pouhé základy, dovolující, a to často jen stěží, vykreslit pouze půdorys zástavby, a zbylých $50 \%$ zachovaných v obtížně rekonstruovatelném prŕizemí, brání v jednoznačném rozlišení mezi domy a nádvořími. Domníváme se, že zodpovězení převážné většiny otázek by nedovolil ani stavebně historický průzkum, ani archeologický výzkum. Proto je v každém prŕípadě nezbytné přistupovat ke všem modelům zástavby obou jader velmi opatrně. S větši mírou pravděpodobnosti snad můžeme přijmout pouze model dvou hradních jader.

První z jader na jihozápadním skalním suku uvozuje podle obou autorů padací most zpř́istupňující vlastní předhradí při patě suku (Durdík 1999, 500). Tím se ovšem do určité míry vymyká první jádro hradu Skály definici ganerbenburgu podané T. Durdíkem $(1999,142)$, který uvádí, že samostatní majitelé „(...) měli větš̌inou vnější opevněni eventuálně hospodářské a provozni části hradu ve společném vlastnictvi". Odtud se budovou (dle T. Durdíka), či věží (dle D. Menclové), vystoupalo do úrovně jádra a po mostě přešlo do parkánu (př́íhrádku) a odtud bránou do nádvoří sevřeného dvěma paláci (obytnými budovami). Oba paláce, jihozápadní o vnitřních rozměrech zhruba $4 \times 5 \mathrm{~m}$, severovýchodní o vnitřních rozměrech zhruba $4 \times 3 \mathrm{~m}$, nejsou vnitřně děleny, takže mají spíše charakter věže. Otázkou ovšem zůstává, proč autoři nespojili domnělé jádro se dvěma paláci a nádvořím do jedné trojdílné budovy. Již uvedení této možnosti naznačuje, jak je dispozice hradu nejasná. Nejasné je i opevnění jádra na jihovýchodní straně a především jeho napojení na hradbu severovýchodního jádra, které by uzavřelo prstenec společného opevnění.

Druhému jádru autoři přisuzují hranolovou věž o vnitřních rozměrech přibližně $3 \times 3 \mathrm{~m}$, dle T. Durdíka $(1999,500)$ asi obytnou. Další zástavbu tvoří nepravidelná plocha vymezená obvodovým zdivem, př́ičně rozdělená na dvě třetiny při severovýchodní straně a jednu třetinu na straně protilehlé. Tu dělí př́íčka na jihovýchodní, menší část, považovanou T. Durdíkem (1999, 500) za nádvoří, zatímco severozápadní část s vnitřní plochou zhruba $3 \times 10 \mathrm{~m}$ interpretuje jako palác. D. Menclová (1972a, 99) považuje celou jihozápadní třetinu za obytnou budovu, 
tedy za dvojdílný palác o vnitřní rozloze zhruba $9 \times 10 \mathrm{~m}$. Zbylé dvě třetiny při severovýchodní straně oba autoři svorně spojují s nádvořím, asi vybaveným zástavbou hospodářských a provozních staveb. Z provozního hlediska však řešení takovéto dispozice mohlo uživatelům vyhovovat jen stěží. Prostor vymezený pro hospodářské a provozní účely zpř́istupňoval průchod palácem (obytnou stavbou) sloužícím především k reprezentaci a odpočinku.

Je zřejmé, že i při rozboru modelů dispozice sídla stojíme před řadou nezodpovězených otázek plynoucích z malého počtu informací, jen částečně doplnitelných dalším výzkumem a průzkumem. Zdá se, že s velkou mírou pravděpodobnosti náleží hrad Skála $\mathrm{k}$ hradům $\mathrm{s}$ více (se dvěma) hradními jádry. Naše informace o dynamickém systému nám jej však nedovolují zařadit mezi hrady vznikající z potřeb vlastnictví formy „v nedílu“ nebo „ve spolku“. D. Menclová (1972a, 99) sice předpokládá, že ve svých počátcích byl hrad menší a k jeho dostavbě do ,,...) dnešního rozsahu (...)“ došlo až za držby Břeňkem, co však bylo předmětem dostavby, ani důvod tohoto rozšíření, nevysvětluje. Oproti tomu se k době rozšíření nabízí již společné vlastnictví bratř́i Břeňka a Půty někdy mezi rokem 1379 a rokem 1385. Avšak tato krátkodobá držba hradu dvěma majiteli si jen stěží mohla vyžádat přístavbu druhého jádra. Je méně pravděpodobná již i proto, že oba majitelé měli vlastní sídla na svých statcích. Břeněk seděl na Švihově a Půta v roce 1380 držel hrad Rábí. Současné držení hradu dvěma samostatnými majiteli dobové písemné záznamy tedy jednoznačně nedokládají a ani spojení s dostavbou hradního jádra, které naznačuje D. Menclová (1972a, 99), nemá opodstatnění.

Předložená situace nás nutí položit si v obecné rovině otázku, jakou funkci více jader na hradech plnilo. Musela jádra vždy důsledně sloužit pouze několika majitelům hradu? Nepochybně se jednalo o jednu z významných funkcí této hradní dispozice, zdá se však, že nemusela vždy hradní dispozici predikovat. Právě hrad Skála se zdá být takovým příkladem. Jednoznačný doklad společných majitelů hradu sice nemáme, dvě hradní jádra se však jeví jako velmi pravděpodobná. Blízkost obou jader, v jiných př́ípadech i spojení některými částmi sídla (např. obvodovou hradbou, předhradím) nedovoluje předpokládat dva různé majitele s negativními interpersonálními vztahy. At' se již jednalo o vazbu př́ibuzenskou, nebo společenskou, musel být vztah mezi majiteli korektní. V př́ípadě znesváření majitelů bylo třeba hledat urovnání vztahu formou dohody, nebot' vyhrocení do agrese by znamenalo boj v ,jednom domě“. Vedle vlastníků sedících na jednotlivých hradních jádrech však mohla být pravděpodobně tato jádra obsazena i majitelem, obývajícím jedno jádro, a jeho podřízeným, sedícím na jádře druhém. Nelze dokonce vyloučit, že vztah nadřízený - podřízený, např́ílad majitel - purkrabí, majitel - člen jeho družiny, mohl být častější než vztah „hrad v nedílu“ nebo „hrad ve spolku“, ačkoliv první nejsou, na rozdíl od druhých, uváděny v písemných záznamech. Důvodem absence vztahu nadřízený - podřízený v dobových zápisech lze přičíst tomu, že se nejednalo o vztahy vlastnické, ale pouze o vztahy pracovní. Takový vztah nemusel být na každém hradě uplatněn a nikoli každý takový vztah muselo nutně doprovázet zbudování dvou či více hradních jader.

Dokladem postoupení hradu Choustníku bratry Benešem a Janem Petrovi z Rožmberku v roce 1322 přiznává Beneš rozdělení sídla mezi něho a bratra (RBM III, 314-315 č. 775). Listina je jedním z mála dokladů informujících nás výslovně o rozdělení sídla, zřejmě však nedokládá, jak zjistili J. Varhaník-J. Zavřel (1994, 37-43), „(...) důsledné stavební rozděleni hradu, který zpočátku oba bratři drželi v nedilu, ale jen o úpravy, umožňující soužití dvou majitelư". Ǩadu dalších hradů spojovaných v literatuře s užíváním v nedílu nebo ve spolku uvádí M. B. Soukup $(2005,583)$. Cílem této práce však není soupis sídel, u nichž se forma užívání více majiteli objevuje v písemných pramenech.

Naopak chceme v závěru práce upozornit na několik př́íkladů sídel s možným rozdělením hradních jader a problém s jejich interpretací. Jedním z nich je hrad Valdštejn (k. ú. Mašov u Turnova, okr. Semily; obr. 3; Gabriel-Macek 1992, 170-171, 174) nebo bezejmenný hrad s pomístním názvem Pustý zámek (k. ú. Zakšín, okr. Česká Lípa; obr. 4; Gabriel-Panáček 2000), oba se stopami zástavby na pískovcových sucích, s vlastními horizontálními či vertikálními př́stupy, avšak bez doloženého propojení společným opevněním a předhradím. Může k nim náležet i rovněž na pískovci založený hrad Rotštejn (k. ú. Bělá u Turnova, okr. Semily; obr. 5; 


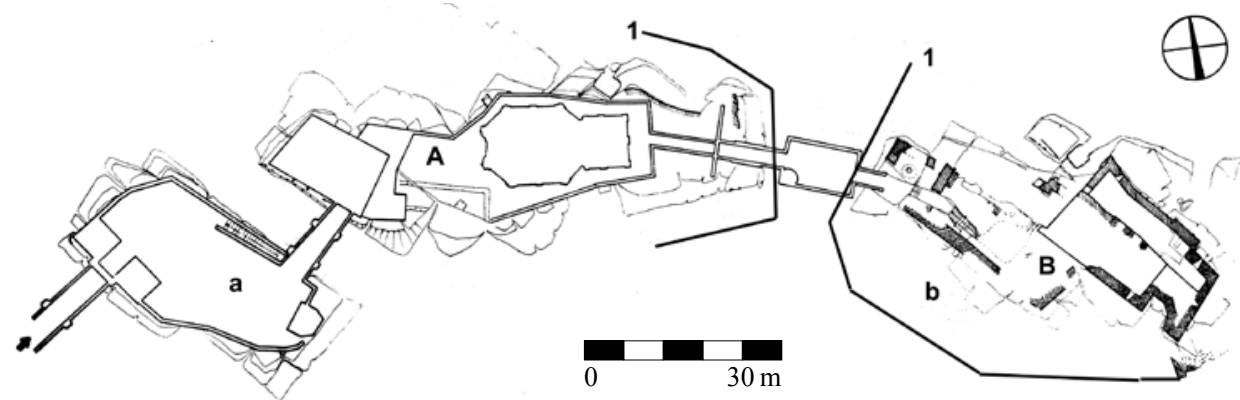

Obr. 3. Plán hradu Valdštejna. A - západní jádro; a - západní předhradí; B - jižní jádro; b - jižní předhradí; 1 - hranice částí hradu. Podle Gabriel-Macek 1992.

Abb. 3. Plan von Burg Waldstein. A - westlicher Burgkern; a - westliche Vorburg; B - südlicher Burgkern; b - südliche Vorburg; 1 - Grenze der Burgteile. Nach Gabriel-Macek 1992.

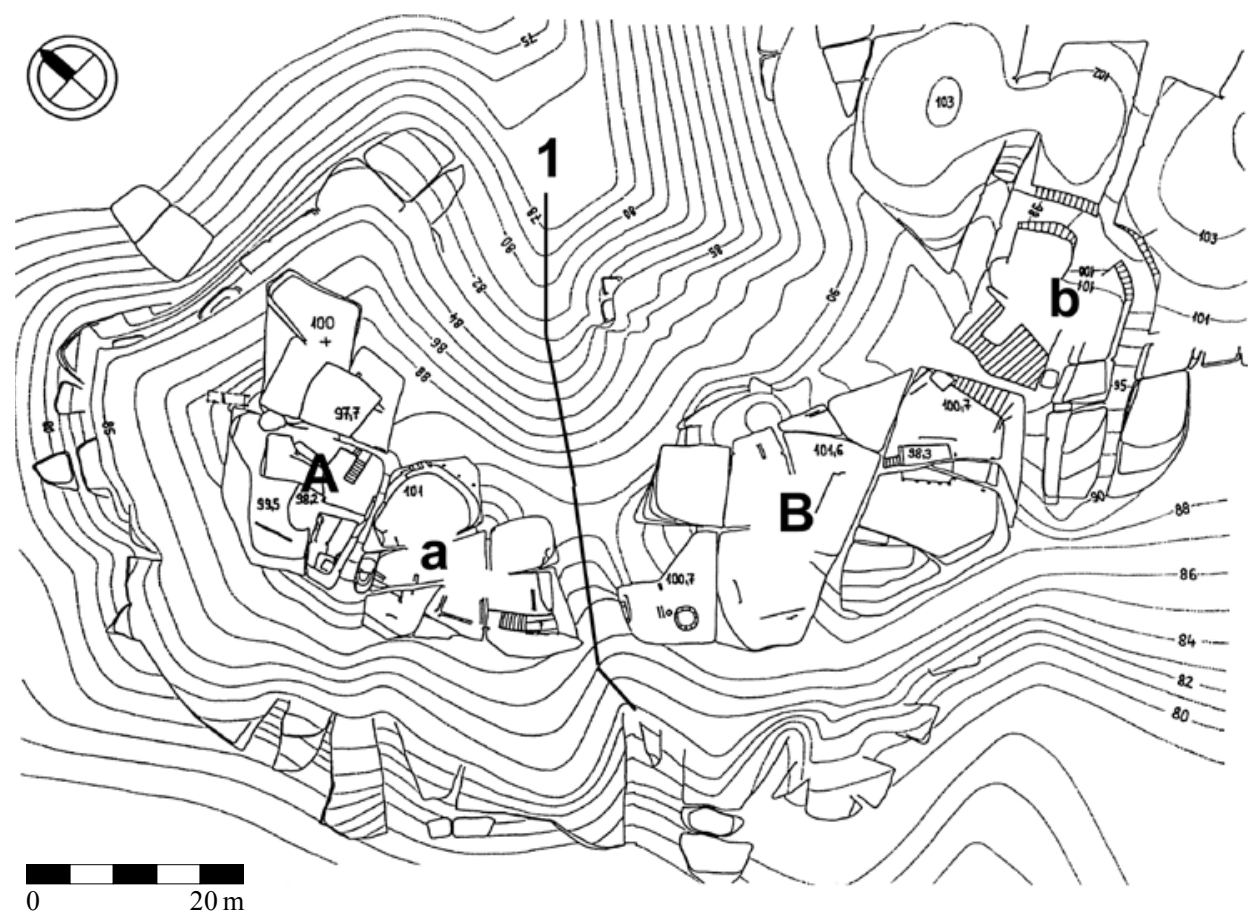

Obr. 4. Plán bezejmenného hradu u Zakšína s pomístním názvem Pustý zámek. A-severozápadní jádro; a - severozápadní předhradí; B - jihovýchodní jádro; b - jihovýchodní předhradí; 1 - hranice částí hradu. Podle Gabriel-Panáček 2000. Abb. 4. Plan einer namenlosen Burg bei Zakšín mit der Flurbezeichnung Wüstes Schloss. A - nordwestlicher Burgkern; a - nordwestliche Vorburg; B - südöstlicher Burgkern; b - südöstliche Vorburg; 1 - Grenze der Burgteile. Nach GabrielPanáček 2000.

Gabriel 2008, 42, 44-45) a s jádry vystupujícími nad rozsáhlé opevněné předhradí řadí mezi ganerbenburgy (dvojhrady) J. Čížek-J. Slavík $(1998,182)$ hrad Adršpach (k. ú. Dolní Adršpach, okr. Náchod). Všechny tyto hrady však mohou představovat i tradiční typ sídla s jediným hradním jádrem, které obsahuje palác na jednom skalním bloku a věž na bloku druhém. Lišily by se tak od hradů, které mají na pískovcovém bloku založenu pouze věž, zatímco palác, dosud ovšem 


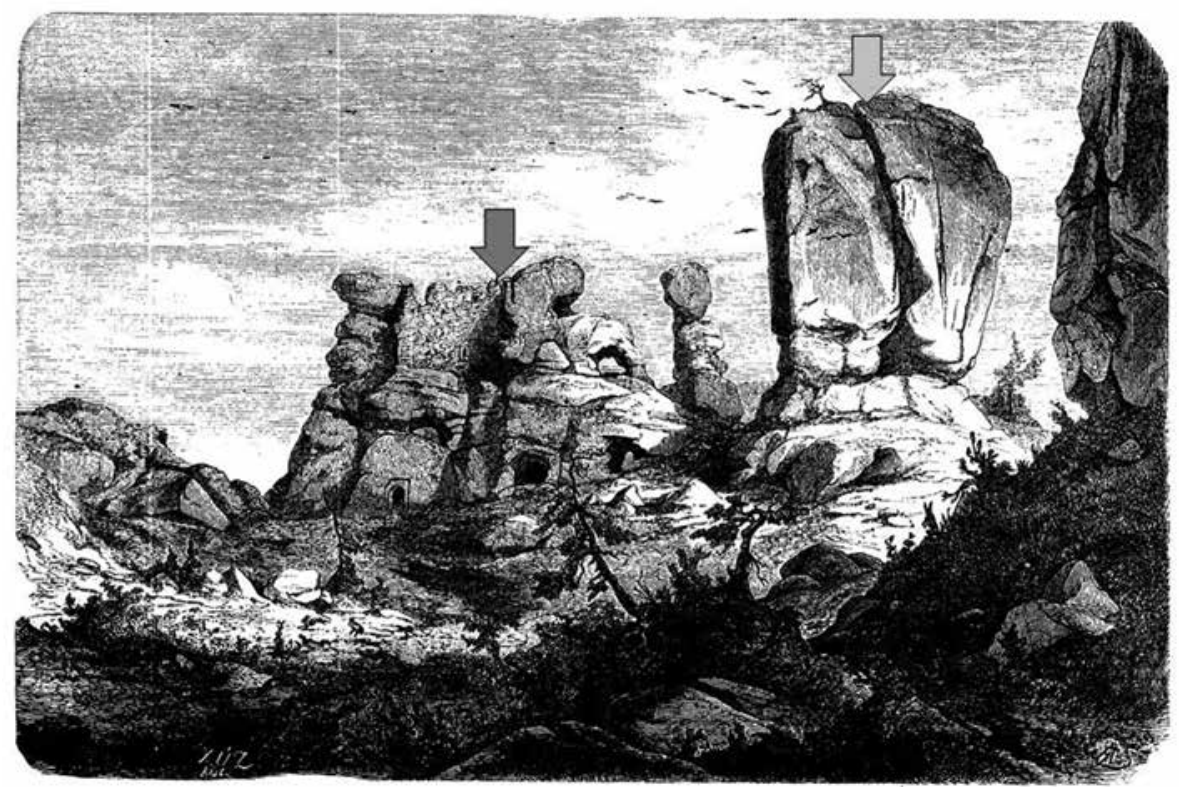

Obr. 5. Grafika hradu Rotštejna od A. Levého se dvěma částmi hradu na skalních blocích, vyznačených šipkami. Podle Gabriel-Ebel 1992.

Abb. 5. Grafik mit Burg Rotstein von A. Levý mit zwei Burgteilen auf mit Pfeilen gekennzeichneten Felsblöcken. Nach Gabriel-Ebel 1992.

toliko předpokládaný, byl zbudován někde u paty skalního suku. Pro jednoznačné zodpovězení této otázky nám však zatím chybí informace.

Přesvědčivější je již výše zmiňovaný hrad Trosky. Jeho dispozice i forma staveb ukazuje na hrad se dvěma jádry. K jednomu náleží věž, pojmenovaná dnes Panna, a zřejmě dvojdílný palác pod ní, $\mathrm{k}$ druhému jádru na západní straně věž Baba s nevelkým palácem při patě skály. Mezi nimi k jižní obvodové hradbě přisedá zhruba $30 \mathrm{~m}$ dlouhá budova, před kterou se ve stejné délce táhne nádvoří, př́istupné z protáhlého předhradí na severní straně (obr. 6).

Jisté souvislosti s hrady obsahujícími více jader nabízí i hrad Bezděz (k. ú. Bezděz, okr. Česká Lípa). Královské založení sídla na počátku 70. let 13. století dalo vznik tzv. Královskému a Purkrabskému paláci, válcovému bergfritu a kapli. Krátce poté následovala druhá stavební aktivita, rozšiřující hrad o další díl, opět se dvěma paláci, tzv. Manskými (naposledy GabrielKursová 2016). Pomineme-li starší jádro se dvěma obytnými jednotkami, větší, interpretovanou jako obydlí panovníka, a menší, prripsanou purkrabímu, překvapí v mladším jádru, odděleném zdí s malou brankou, další dvě bytové jednotky stejného uspořádání jako tzv. Purkrabský palác a jádro tzv. Královského paláce. Hrad tedy obsahuje čtyři obytné jednotky, ve dvojicích oddělených od sebe zdí (obr. 7). Jestliže dovedeme téměř s jistotou interpretovat bytovou jednotku panovníka, vloženou do komplexu dalších místností, a přijmeme-li druhý palác ve starším jádře jako obydlí purkrabího, důvod výstavby dvou dalších paláců v mladším jádře vysvětlit neumíme. Zdá se však zřejmé, že představa o ubytovacím prostoru manů a jejich družin není př́liš pravděpodobná, nebot' byly, stejně jako starší obytné jednotky, zřízeny pro rodinu vyšší společnosti. Zástavba se tak jeví jako čtyři hradní jádra s jedinou „univerzální“ obrannou věží. Vzájemné oddělení paláců mohlo být pouze ideové, avšak s ohledem na původní projekt vzniklo rozdělení mezi staršími a mladšími jádry. Starší dvojice měla společný bergfrit, prostupující opevněním, mladší dvojici pak mohla sloužit tzv. Čertova věž, která je rovněž součástí opevnění, případně 


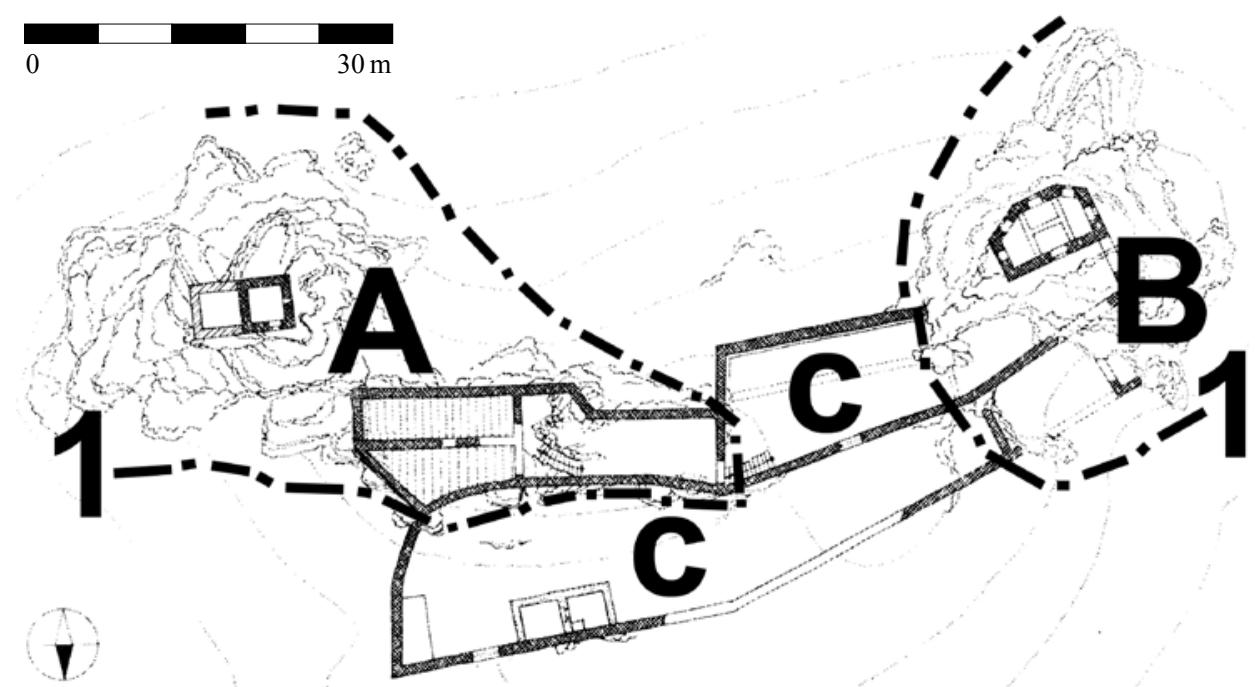

Obr. 6. Plán hradu Trosky. A - východní jádro; B - západní jádro; c - společná předhradí; 1 - hranice částí hradu. Podle Svoboda 1991.

Abb. 6. Plan von Burg Trosky. A - östlicher Burgkern; B - westlicher Burgkern; c - gemeinsame Vorburg; 1 - Grenze der Burgteile. Nach Svoboda 1991.

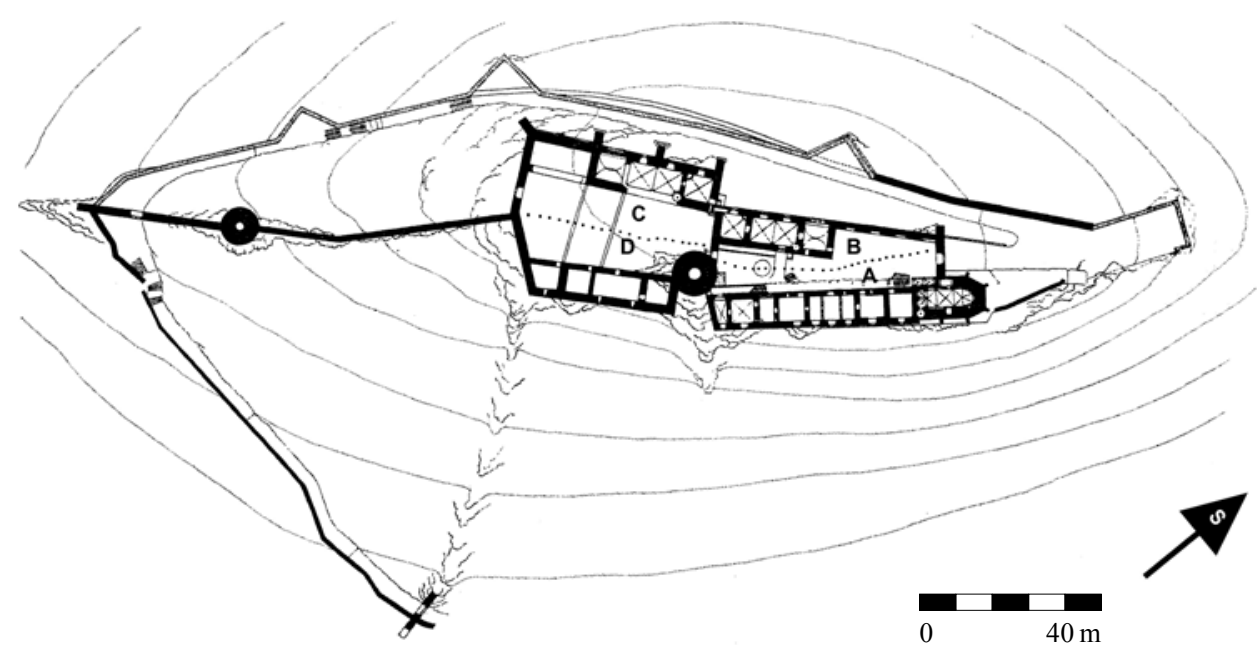

Obr. 7. Plán hradu Bezděz. A, B, C, D - čtyři hradní jádra, odlišená dle modelu pouze ideově (tečkované linky). Podel Gabriel-Kursová 2016.

Abb. 7. Plan von Burg Bösig. A, B, C, D - vier, modellhaft nur gedanklich getrennte Burgkerne (punktierte Linien). Nach Gabriel-Kursová 2016.

hlavní věž, využívaná v takovém případě všemi čtyřmi jádry, jak se zdá pravděpodobnější. Takový model lze aplikovat i na řadu dalších hradů, kde však dělení na jádra vykazuje menší míru jistoty než hrady s jádry oddělenými jednoznačně zdí. Hledání, rozklad a interpretace těchto př́ípadů však není cílem tohoto článku. 


\section{Prameny a literatura}

ALSDORF, F. K., 1980: Untersuchungen zur Rechtsgestalt und Teilung deutscher Ganerbenburgen. Rechtshistorische Reihe 9. Frankfurt/M. - Bern - Cirencester, U. K.

ČÍŽEK, J.-SLAVÍK, J., 1998: Adršpach, hrad Jana Lucemburského? - Adršpach, Königsburg des Johann von Luxemburg?, CB 6, 171-186.

DURDÍK, T., 1977: K chronologii obytných věží českého středověku - Zur Chronologie der Wohntürme tschechischer mittelalterlichen Burgen, AH 2, 221-228.

- 1984: České hrady. Praha.

- 1999: Ilustrovaná encyklopedie českých hradů. Praha.

- 2008: Ilustrovaná encyklopedie českých hradů. Dodatky 3. Praha.

- 2008a: České hrady. Druhé upravené vydání. Praha.

DURDÍK, T.-BOLINA, P., 2001: Středověké hrady v Čechách a na Moravě - Mittelalterliche Burgen in Böhmen und Mähren. Praha.

GABRIEL, F., 2002: Quo vadis vědo o hradech? - Quo vadis Burgenwissenschaft?, CB 8, 499-502.

- 2008: Vztah stavby „věž“ k typu „skalní hrad“ v severních Čechách - Beziehungdes Baus „Turm“ zum Typ „Felsenburg“ in Nordböhmen, CB 11, 31-52.

GABRIEL, F.-EBEL, M., 1992: Stavebně historický průzkum. Strojopis, archiv autorů.

GABRIEL, F.-KURSOVÁ, L., 2016: Královský palác a kaple na hradě Bezdězu a jejich proměny - Die Entwicklung des Königlichen Palas und Kapelle der Burg Bezděz, CB 16, 5-43.

- 2017: Otázky k rozsahu a podobě hradu Skály (Bischofstein) - Fragen zur Größe der Burg Skály (Bischofstein), CB 17, 5-34.

GABRIEL, F.-MACEK, P., 1992: Stavební vývoj hradu Valdštejna - Die Bauentwicklung der Burg Waldstein, AH 17, 163-175.

GABRIEL, F.-PANÁČEK, J., 2000: Pustý zámek u Zakšína - Die verödete Burg „Pustý zámek“ bei Zakšín, CB 7, 111-125

GABRIEL, F.-SMETANA, J., 1981: K datování a funkci stř̌edověkých opevnění v Českém Švýcarsku - Zur Datierung und Funktion de mittelalterlichen Befestigungen in der Böhmischen Schweiz, AH 6, 33-62.

KUKAL, Z. a kol., 2010: Hrady Čech a Moravy z čeho jsou a na čem stojí. Praha.

LC III-IV: Libri confirmationum ad beneficia ecclesiastica pragensem per archidioecesim III-IV. (Emler, J., ed.). Praha 1879.

LEHKÝ, I., 2012: Malý „obř́i hrad“ Rýzmbur - Die „,kleine“ Burg „Riesenburg“ (Rýzmburk). In: Hrady českého severozápadu (Kuljavceva Hlavová, J.-Kotyza, O.-Sýkora, M., edd.), 149-203. Most.

MENCLOVÁ, D., 1972: České hrady 1. Praha.

- 1972a: České hrady 2. Praha.

MĚŘÍNSKÝ, Z.-PLAČEK, M., 1988: Nástin vývoje hradní architektury vrcholného středověku na Moravě a ve Slezku do období husitských válek - Abriß der Entwicklung der Burgarchitektur der Blütezeit des Mittelalters in Mähren und Schlesien bis zu hussitischen Kriegen, AH 13, 217-249.

PACHNER, J., 2012: Předsunuté opevnění nad přístupovou cestou hradu Šumburku - Vorwerk oberhalb des Zugangswegs zur Burg Schönburg (Šumburk). In: Hrady českého severozápadu (Kuljavceva Hlavová, J.-Kotyza, O.-Sýkora, M., edd.), 257-269. Most.

PANÁČEK, J., 2004: Popis českolipského hradu roku 1502 - Beschreibung der Burg in Česká Lípa (Böhmisch Leipa) aus dem Jahre 1502, CB 9, 371-381.

PIPER, O., 1912: Burgenkunde. München.

RBM III: Regesta diplomatica nec non epistolaria Bohemiae et Moraviae III (Emler, J., ed.). Praha 1890.

SEDLÁČEK, A., 1996: Hrady zámky a tvrze království českého IX. Praha.

SOUKUP, M. B., 2005: Ganerbenburg a rozdělené hrady, AR LVII, 580-585.

SVOBODA, L., 1991: Trosky. Praha - Pardubice.

UNGER, J., 1999: Život na lelekovickém hradě ve 14. století. Antropologická sociokulturní studie - Das Leben auf der Burg Lelekovice im 14. Jahrhundert: Antropologische soziokulturelle Studie. Brno.

VANĚČEK, V., 1976: Dějiny státu a práva v Československu. Praha.

VARHANÍK, J.-ZAVŘEL, J., 1994: Povrchový průzkum hradu Choustníka - Untersuchung der Burg Choustník, AH 19, 37-49.

WOHNTÜRME 2002: Wohntürme (Müller, H., ed.). Langenweißbach. 


\section{Zusammenfassung}

\section{Typenmäßige Zuordnung der Burg Skála (Burg Fels) bei Přeštice}

Die Burg Skála (Katastergebiet Zálesí bei Př́íchovice, Bezirk Pilsen-Süd) reiht sich in der Fachliteratur zu den als Ganerbenburg bezeichneten Burgen, was ein Terminus aus der mittelalterlichen deutschen Umgebung ist und danach auch definiert wird. Für die tschechischen Gebiete wurde er von T. Durdík $(1999,142)$ definiert als Burgen mit mehreren Wohnsitzen eigenständiger Besitzer innerhalb des eigentlichen Burgkerns, die jeweils mit einem Palas und einem Turm ausgestattet waren, während sich die Außenbefestigungen, Wirtschafts- und Betriebsteile der Burg im gemeinsamen Besitz befanden. Die Frage der Definition wurde erneut von M. B. Soukup (2005) aufgeworfen, der den historischen Terminus Ganerbenburg (,ungeteilte Burg“ oder „Gemeinschaftsburg“) als Rechtsbegriff eines dynamischen Systems von dem Begriff „Burg mit mehreren Kernen“, die zur formalen Struktur der historischen Bauten gehören, trennte. Das Problem liegt jedoch nicht in der bloßen Bezeichnung eines Burgtyps, sondern in der Definition, die gleichzeitig beide Arten historische Quellen miteinander koppelt, die nicht miteinander korrelieren, sondern eine Kausalbeziehung haben können.

Für die Burg Skála finden wir in den schriftlichen Quellen keinen eindeutigen Beleg für eine ungeteilte Nutzung, auch nicht für eine Nutzung als Gemeinschaftsburg. Es gibt jedoch den Anschein, dass wir ihre Einordnung unter Burgen mit mehreren (mit zwei) Kernen akzeptieren können. Jedoch auch aus dieser Sicht treffen wir auf eine Reihe von Problemen (Abgrenzung der einzelnen Burgteile, Bestimmung ihrer Funktion, Bestimmung der Funktion des Turms und seine Bedeutung für die Bestimmung des Burgkerns und Abgrenzung des Begriffes Palas) und eine Einordnung ist nicht eindeutig. Die beobachtete Situation stellt uns vor die Frage, ob der Burgkern immer nur mehreren Burgbesitzern gedient haben musste, wie etwa Burg Choustník zeigt, oder ob er auch anderen Beziehungen unterlag (z.B. Vorgesetzter - Untergebener) und ob in allen Fällen die Definition von Burgen mit mehreren Kernen strikt eingehalten wird. An einigen Beispielen - Burg Waldstein (Katastergebiet Mašov bei Turnov, Bezirk Semily; GabrielMacek 1992, 170-171, 174), Wüstes Schloss / Pustý zámek (Katastergebiet Zakšín, Bezirk Česká Lípa; Gabriel-Panáček 2000), Burg Rotstein (Katastergebiet Bělá bei Turnov, Bezirk Semily; Gabriel 2008, 42, 44-45) oder Burg Adersbach (Katastergebiet Dolní Adršpach, Bezirk Náchod; Č́žzek-Slavík 1998, 182) - weisen wir darauf hin, dass diese Burgen auch Sitze mit einem einzigen Burgkern darstellen können, der einen Palas auf einem Felsblock und einen Turm auf einem anderen enthält. Bei der Burg Trosky (Katastergebiet Troskovice, Bezirk Semily) ist die Aufteilung erkennbar eindeutig, während wir bei Burg Bösig/Bezděz (Katastergebiet Bezděz, Bezirk Česká Lípa) lediglich mit einer gedanklichen Trennung rechnen müssen.

doc. PhDr. František Gabriel, Ph.D., Katedra archeologie Fakulty filozofické Západočeské univerzity v Plzni, Sedláčkova 15, 30614 Plzeň, Česká republika, pu-uvpd-cl@volny.cz

PhDr. Lucie Kursová, Regionální muzeum v Teplicích, Česká republika, kursova.rmt@sezmam.cz 
